\title{
Birth Month and Prevalence of Atopic Dermatitis in Children Under 3 Years in Antananarivo, Madagascar
}

This article was published in the following Dove Press journal:

Journal of Asthma and Allergy

\author{
Fandresena Arilala \\ Sendrasoa (iD) \\ Volatantely Tobiniaina Ratovonjanahary \\ Naina Harinjara Razanakoto \\ Mendrika Fifaliana \\ Rakotoarisaona \\ Onivola Raharolahy (D) \\ Malalaniaina Andrianarison \\ Irina Mamisoa Ranaivo (D) \\ Viviane Estelle Mbotinirina (iD) \\ Moril Sata \\ Lala Soavina Ramarozatovo \\ Fahafahantsoa Rapelanoro \\ Rabenja \\ Department of Dermatology, Faculty of \\ Medicine, University of Antananarivo, \\ Antananarivo, Madagascar
}

Background: Several studies have been done to evaluate the relationship between month of birth and atopic diseases but the results are contradictory.

Objective: We aim to evaluate the correlation between the month of birth and the prevalence of AD in Malagasy children less than 3 years.

Methods: A case-control study was conducted based on patients' data of the department of Dermatology in the University Hospital Joseph Raseta Befelatanana (UH/JRB) Antananarivo. It included 438 children less than 3 years seen in this department between January 2010 and December 2019. For each atopic dermatitis (AD) patient, two age-and sexmatched controls without a history of AD were selected from the same period.

Results: This study included 146 AD cases and 292 non-AD controls. Our case-control study found that there is a statistically significant correlation between birth month and risk of AD in Malagasy children $<3$ years. Compared with people born in December, people born in April had the highest risk of AD (OR: 2.11, 95\% CI 0.93-4.78), followed by people born in March (OR: 1.52, 95\% CI 0.79-2,88). Asthma, allergic rhinitis and allergic conjunctivitis were significantly correlated with $\mathrm{AD}$ in our patients.

Conclusion: Our case-control study found that being born in April and March (dry season) may be associated with an increased risk of AD.

Keywords: birth month, atopic dermatitis, children, Madagascar

\section{Background}

Atopic dermatitis (AD) is a chronic or recurrent inflammatory skin disease characterized by xerotic and pruritic skin. The etiology of AD is multifactorial with interaction between genetics, immune and environmental factors. ${ }^{1}$ As in industrialized countries, the incidence of $\mathrm{AD}$ in patients $<15$ years increased from $1.02 \%$ in 1999 to $5.6 \%$ in 2019 in Madagascar. ${ }^{2,3}$

Some studies conducted in white populations showed an association between birth season and AD. ${ }^{4-6}$ A previous cross-sectional study in Antananarivo Madagascar reported that children born in the dry season had the highest risk of $\mathrm{AD}{ }^{7}$ In order to affirm this result, we aimed to evaluate the correlation between the month of birth and the prevalence of AD in Malagasy children less than 3 years old by using an appropriate study design.

\section{Methods}

A case-control study was conducted based on patients' data at the department of dermatology in the University Hospital Joseph Raseta Befelatanana (UH/JRB) Antananarivo which is the hospital reference center in the capital of Madagascar.
Correspondence: Fandresena Arilala

Department of Dermatology, Faculty of Medicine Antananarivo, Antananarivo

I0I, Madagascar

Tel +26I 34l 420496

Email nasendrefa@yahoo.fr 
We included children less than 3 years old seen in the department of dermatology in the UH/JRB Antananarivo between January 2010 and December 2019.

We included 438 children aged 3 years and younger. $\mathrm{AD}$ was diagnosed by a dermatologist according to the criteria of United Kingdom Working Party modified. For each AD patient, two age-and sex-matched controls without a history of AD were selected from the same period.

This study was approved by the Ethics Committee of the University Hospital Joseph Raseta Befelatanana Antananarivo Madagascar, and it was conducted in accordance with the Declaration of Helsinki. Study participants and their parents were informed about the study procedures and written informed consent was obtained.

\section{Statistical Analysis}

Statistical analysis was conducted using STATA software version 12. All data were analyzed using a Chi-squared $\left(\mathrm{X}^{2}\right)$ test for differences in the prevalence of related $\mathrm{AD}$. Odds ratios (ORs) and 95\% confidence intervals (CIs) were computed with the logistic regression analysis after taking the confounding variables into account. Significance was set at $p<0.05$.

\section{Results}

A total of 438 children $\leq 3$ years were included: $146 \mathrm{AD}$ cases and 292 non-AD controls. The baseline characteristics of the children included is shown in Table 1.

The two groups were matched by gender and age. A significant association was found between the prevalence of $\mathrm{AD}$ and the month of birth. The fewest children with AD were born in December (4.1\%, OR: 0.41, CI

Table I The Characteristics of Children with $A D$ and Without AD (Controls)

\begin{tabular}{|l|l|l|}
\hline & AND (\%) & Controls N (\%) \\
\hline $\begin{array}{c}\text { Gender } \\
\text { Female } \\
\text { Male }\end{array}$ & $74(506)$ & $148(507)$ \\
& $72(49.3)$ & $144(49.3)$ \\
\hline $\begin{array}{l}\text { Age (months) } \\
0-12\end{array}$ & $94(64.3 \%)$ & $187(64.04 \%)$ \\
I3-24 & $42(28.76 \%)$ & $84(28.76 \%)$ \\
$25-36$ & $10(6.84 \%)$ & $21(7.19 \%)$ \\
\hline $\begin{array}{c}\text { Geographic origin } \\
\text { Rural }\end{array}$ & $73(50 \%)$ & $144(49.3 \%)$ \\
Urban & $73(50 \%)$ & $148(50.6 \%)$ \\
\hline
\end{tabular}

Table 2 Correlation Between Month of Birth and Incidence of $A D$

\begin{tabular}{|c|c|c|c|c|c|}
\hline & $\begin{array}{l}\text { AD } \\
\text { Cases } \\
(\mathrm{N}=\mid 46) \\
n(\%)\end{array}$ & $\begin{array}{l}\text { Non-AD } \\
\text { Controls } \\
(\mathrm{N}=292) \\
\mathrm{n}(\%)\end{array}$ & OR & $\begin{array}{l}\text { CI } \\
(95 \%)\end{array}$ & $P$ \\
\hline January & $12(8.21)$ & $27(9.24)$ & 0,97 & $0.49-1.96$ & 0.35 \\
\hline February & $15(10.27)$ & $28(9.58)$ & 1.17 & $0.5 I-2.14$ & 0.29 \\
\hline March & $21(14.38)$ & $29(9.93)$ & 1.52 & $0.79-2.88$ & 0.04 \\
\hline April & $15(10.27)$ & $15(5.13)$ & 2.11 & $0.93-4.78$ & 0.03 \\
\hline May & $14(9.58)$ & $21(7.19)$ & 1.36 & $0.62-2.92$ & 0.14 \\
\hline June & $12(8.21)$ & $23(7.87)$ & 1.04 & $0,46-2,27$ & 0,92 \\
\hline July & $9(6.16)$ & $2 I(7 . I I)$ & 0.84 & $0.33-1.99$ & 0.84 \\
\hline August & $10(6.84)$ & $20(6.84)$ & I & $0.4-2.31$ & I \\
\hline September & $12(8.21)$ & $27(9.24)$ & 0.85 & $0.39-1.86$ & 0.72 \\
\hline October & $12(8.21)$ & $33(11.3)$ & 0.76 & $0.31-1.45$ & 0.39 \\
\hline November & $8(5.47)$ & $20(6.84)$ & 0.68 & $0.21-1.72$ & 0.48 \\
\hline December & $6(4.1)$ & $28(9.58)$ & $0.4 I$ & $0.13-1.02$ & 0.05 \\
\hline
\end{tabular}

95\%: 0.13-1.02), and the most were born in April (10.27\%, OR: 2.11; CI 95\%: 0.93-4.78) and March (14.38\%, OR: 1.52; CI 95\%: 0.79-2,88). The correlation between month of birth and incidence of AD is shown in Table 2.

Compared with children without $\mathrm{AD}$, those with $\mathrm{AD}$ had a higher proportion of asthma ( $14,4 \%$ vs $2.12 \%$; OR 7.27, 95\% CI: 2.47-25,72; $p$ 0.000006), allergic rhinitis (8.9\% vs $2.1 \%$; OR:3.54, CI 95\%: $1.13-12,15 ; p 0.01$ ). Family atopy was not associated with the AD risk. The correlation between other medical conditions and $\mathrm{AD}$ is shown in Table 3.

\section{Discussion}

Our case-control study found that there is a statistically significant correlation between birth month and risk of AD. Compared with children born in December (rainy season), those born in April and March (dry season) had the highest risk of AD. In Madagascar, the month with the highest relative humidity is December $(81.5 \%)$, the average rainfall is $278.9 \mathrm{~mm}$. The average humidity in April and March is $74.5 \%$ with an average rainfall at $10.4 \mathrm{~mm}$. Several studies have been done to clarify a relationship between month of birth and atopic diseases but the results are contradictory. Our result was consistent with other studies which found that manifestation of atopy is related to the patient's month of birth. A population-based study in Taiwan found that patients born in December, October and November (dry season) have a higher risk of developing $\mathrm{AD}$; this study hypothesized that the skin 
Table 3 Coexisting Medical Conditions in Children with and without AD

\begin{tabular}{|c|c|c|c|c|c|c|}
\hline & AD Cases & Non-AD Controls & $\mathbf{x}^{2}$ & $\mathbf{p}$ & ORs & $\mathrm{Cl}(95 \%)$ \\
\hline $\begin{array}{l}\text { Allergic rhinitis } \\
\text { No } \\
\text { Yes }\end{array}$ & $\begin{array}{l}122(835 \%) \\
24(16.4 \%)\end{array}$ & $\begin{array}{l}276(945 \%) \\
16(5.4 \%)\end{array}$ & 8.38 & 0.0032 & 2.90 & $1.65-7.04$ \\
\hline $\begin{array}{l}\text { Allergicconjunctivitis } \\
\text { No } \\
\text { Yes }\end{array}$ & $\begin{array}{l}133(91.09 \%) \\
13(8.9 \%)\end{array}$ & $\begin{array}{l}286(97.94 \%) \\
6(2.1 \%)\end{array}$ & 5.96 & 0.01 & 3.54 & $1.13-12.15$ \\
\hline $\begin{array}{l}\text { Asthma } \\
\text { No } \\
\text { Yes }\end{array}$ & $\begin{array}{l}124(85.60 \%) \\
22(14.40 \%)\end{array}$ & $\begin{array}{l}287(97.88 \%) \\
5(2.12 \%)\end{array}$ & 19.11 & 0.000006 & 7.27 & $2.47-25.72$ \\
\hline $\begin{array}{l}\text { Vitiligo } \\
\text { No } \\
\text { Yes }\end{array}$ & $\begin{array}{l}146(100 \%) \\
0(0 \%)\end{array}$ & $\begin{array}{l}277(94.86 \%) \\
15(5.14 \%)\end{array}$ & -0.00 & 0.0020 & & \\
\hline $\begin{array}{l}\text { Urticaria } \\
\text { No } \\
\text { Yes }\end{array}$ & $\begin{array}{l}\text { I } 44 \text { (98.63\%) } \\
2(1.70 \%)\end{array}$ & $\begin{array}{l}290(99.31 \%) \\
2(0.85 \%)\end{array}$ & 0.48 & 0.40 & 2017 & $0.14-28.09$ \\
\hline $\begin{array}{l}\text { Family atopy } \\
\text { No } \\
\text { Yes }\end{array}$ & $\begin{array}{l}89(60.9 \%) \\
57(39.04 \%)\end{array}$ & $\begin{array}{l}269(92.12 \%) \\
23(7.87 \%)\end{array}$ & 36.22 & 1.86 & 7.48 & $4.23-13.45$ \\
\hline $\begin{array}{l}\text { Other medical past history } \\
\text { No } \\
\text { Yes }\end{array}$ & $\begin{array}{l}144(98.6 \%) \\
2(1.36 \%)\end{array}$ & $\begin{array}{l}269(92.12 \%) \\
23(7.87 \%)\end{array}$ & 9.65 & 0.004 & 0.16 & $0018-0.67$ \\
\hline
\end{tabular}

condition is affected by the climate in early infancy. ${ }^{4}$ A Japanese study reported also that children born in autumn (October, November and December) had a higher risk of developing $\mathrm{AD}$ compared to those born in spring (April, May and June). ${ }^{5}$ One study in Armenian pediatric patients in 2018 showed that being born in winter was associated with a lower risk of developing severe $\mathrm{AD}$ when compared to spring. It may be explained by the exposure to grass pollen which is the most significant allergen in Armenia. ${ }^{6}$ In our study, children born in the dry season had a higher risk of $\mathrm{AD}$. So the lack of humidity during the dry season may affect the skin condition. However, other studies in Germany ${ }^{8}$ and in Denmark ${ }^{9}$ found that manifestation of atopy is not related to the patient's month of birth. Several arguments may explain the variability of these results.

Our study showed that allergic rhinitis, allergic conjunctivitis, urticaria and asthma were coexisting diseases associated with the $\mathrm{AD}$ risk. Our findings were consistent with previous investigations suggesting that asthma, ${ }^{10-12}$ allergic rhinitis ${ }^{13,14}$ and allergic conjunctivitis ${ }^{15}$ were correlated with $\mathrm{AD}$. This association may be explained by the "atopic march" which refers to the natural history of allergic diseases as they develop over the course of infancy and childhood. It describes the progression of atopic disorders from $\mathrm{AD}$ in infants to asthma and allergic rhinitis in children. ${ }^{16}$

Our study had limitations; it was a retrospective study so it was a study of association but not direct causation. Prospective studies are still needed to validate the causal relationship between birth month and AD.

\section{Conclusion}

Our case-control study found that being born in April or March (dry season) may be associated with an increased risk of $\mathrm{AD}$. Our study shows also that $\mathrm{AD}$ was associated with asthma, allergic rhinitis, allergic conjunctivitis, and urticaria.

\section{Abbreviations}

$\mathrm{AD}$, atopic dermatitis; UH/JRB, University Hospital Joseph Raseta Befelatanana; OR, odds ratio; CI, confidence Interval.

\section{Acknowledgments}

We are grateful to all participants in this study. 


\section{Disclosure}

The authors report no conflicts of interest in this work.

\section{References}

1. Kantor R, Silverberg JI. Environmental risk factors and their role in the management of atopic dermatitis. Expert Rev Clin Immunol. 2017;13(1):15-26. doi:10.1080/1744666X.2016.1212660

2. Rabenja NL. Atopic dermatitis in infant and child. Thèse de doctorat en médecine. 1999.

3. Sitraka P. Evaluation of the epidemio-clinical aspects of atopic dermatitis 11 years after a study conducted in the University Hospital Joseph Raseta Befelatanana. Thèse de doctorat en médecine. 2019.

4. Kuo CL, Chen TL, Liao CC, et al. Birth month and risk of atopic dermatitis: a nationwide population-based study. Allergy. 2016;71 (11):1626-1631. doi:10.1111/all.12954

5. Kusunoki T, Asai K, Harazaki M, et al. Month of birth and prevalence of atopic dermatitis in schoolchildren: dry skin in early infancy as a possible etiologic factor. $J$ Allergy Clin Immunol. 1999; 103:1148-1152. doi:10.1016/S0091-6749(99)70191-0

6. Sargsyan A, Gupta J, Ghosh D. Association of severe atopic dermatitis with month of birth in Armenian pediatric patients. Pediatr Allergy Immunol. 2018;29(6):655-656. doi:10.1111/pai.12918

7. Sendrasoa FA, Ranaivo IM, Razanakoto NH, et al. Epidemiology and associated factors of atopic dermatitis in Malagasy children. All Asthma Clin Immunol. 2020;16:4. doi:10.1186/s13223-0190398-2
8. Schafer T, Przybilla B, Ring J, et al. Manifestation of atopy is not related to patient's month of birth. Allergy. 1993;48:291-294. doi:10.1111/j.1398-9995.1993.tb00731.x

9. Smith JM, Springett VH. Atopic disease and month of birth. Clin Allergy. 1979;9:153-157. doi:10.1111/j.1365-2222.1979.tb01536.x

10. Marinho SA, Lowe L, Kissen P, Murray CA. Rhinoconjunctivitis in 5-year-old children: a population based birth cohort study. Allergy. 2007;62:385-393. doi:10.1111/j.1398-9995.2006.01294.x

11. Purvis DJ, Thompson JMD, Clark PM, et al. Risk factors for atopic dermatitis in New Zealand children at 3.5 years of age. British $J$ Dermatol. 2005;152(4):742-749. doi:10.1111/j.1365-2133.2005.06 540.x

12. Dizier MH, Margaritte-Jeannin P, Madore AM, et al. The ANO3/ MUC15 locus is associated with eczema in families ascertained through asthma. J Allergy Clin Immunol. 2012;129(6):1547-1553. doi:10.1016/j.jaci.2012.04.010

13. An SY, Choi HG, Kim SW, et al. Analysis of various risk factors predisposing subjects to allergic rhinitis. Asian Pac J Allergy Immunol. 2015;33(2):143-151. doi:10.12932/AP0554.33.2.2015

14. Chang Y, Hwang C, Chen Y, et al. Prevalence of atopic dermatitis, allergic rhinitis and asthma in Taiwan: a national study 2000 to 2007. Acta Dermato Venereologica. 2010;90(6):589-594. doi:10.2340/ 00015555-0963

15. Bielory B, Bielory L. Atopic dermatitis and keratoconjunctivitis. Immunol Allergy Clin North Am. 2010;30(3):323-336. doi:10.1016/ j.iac.2010.06.004

16. Spergel JM, Paller AS. Atopic dermatitis and the atopic march. J Allergy Clin Immunol. 2003;112:S118-S127. doi:10.1016/j.jaci.2003.09.033

\section{Publish your work in this journal}

The Journal of Asthma and Allergy is an international, peer-reviewed open-access journal publishing original research, reports, editorials and commentaries on the following topics: Asthma; Pulmonary physiology; Asthma related clinical health; Clinical immunology and the immunological basis of disease; Pharmacological interventions and new therapies. The manuscript management system is completely online and includes a very quick and fair peer-review system, which is all easy to use. Visit http://www.dovepress.com/testimonials.php to read real quotes from published authors. 